Ecological risks and opportunities from engineered artificial flooding as a means of achieving environmental flow objectives

\author{
Nick Bond $^{1 *}$, Justin Costelloe ${ }^{2}$, Alison King ${ }^{3}$, Danielle Warfe ${ }^{4}$, Paul Reich $^{5}$, and Stephen Balcombe ${ }^{1}$
}

\begin{abstract}
Restoration of floodplain ecosystems through the reinstatement of floods is often hampered by insufficient water as a result of competing human demands. An emerging alternative approach relies on floodplain infrastructure - such as levees, weirs, regulators, and pumps - to control water levels within floodplains without requiring landscapescale overbank floods. This technique, albeit water efficient and capable of achieving some ecological targets, does not mimic the hydraulics, hydrodynamics, and lateral connectivity of natural floods. Engineering approaches like this may risk detrimental ecological outcomes, including reductions in biotic connectivity, river-floodplain productivity, and water quality, and thus may fail to support the range of ecological processes required to sustain healthy river-floodplain systems. Here, we review the potential benefits, risks, and mitigation options associated with engineered artificial flooding. Given the growing challenge of equitable water allocation, further research on and monitoring of engineered floods as a tool to sustain floodplain ecosystems are urgently required.
\end{abstract}

Front Ecol Environ 2014; 12(7): 386-394, doi:10.1890/130259 (published online 19 Jun 2014)

$F_{1}^{\mathrm{lod}}$ oodplain ecosystems are among the most productive landscapes on Earth, providing various direct and indirect goods and services to humans (Tockner et al. 2008), as well as supporting diverse ecological communities (Figure 1). In many regions, however, river regulation to support agriculture and energy production, and to prevent floodrelated damage to settlements, has removed the very floods upon which these ecosystems and their biological communities depend (Nilsson et al. 2005; Vörösmarty et

\section{In a nutshell:}

- Human demand for fresh water has caused global reductions in the productivity of floodplain ecosystems

- In areas facing water stress, engineering solutions are increasingly being used to engineer artificial floods in an effort to simultaneously meet human needs and ecosystem water requirements

- These approaches may improve floodplain forest condition, but also risk failing to maintain and restore key ecosystem processes and river-floodplain connectivity that support diverse, productive riverine ecosystems

- During the planning phase, water savings from such infrastructure must be carefully weighed against restoration target and implementation should be guided by clearly defined objectives, well-designed monitoring systems, and ongoing adaptive management

\footnotetext{
${ }^{1}$ Australian Rivers Institute, Griffith University, Nathan, Australia *(n.bond@griffith.edu.au); ${ }^{2}$ School of Engineering, University of Melbourne, Parkville, Australia; ${ }^{3}$ Research Institute for the Environment and Livelihoods, Charles Darwin University, Darwin, Australia; ${ }^{4}$ Centre of Excellence in Natural Resource Management, The University of Western Australia, Albany, Australia; ${ }^{5}$ Arthur Rylah Institute for Environmental Research, Department of Environment and Primary Industries, Heidelberg, Australia
}

al. 2010). The past decade has been characterized by largescale efforts to reverse these historical impacts of flow regulation, and the concept of environmental flows is now a central component of water resource planning in most parts of the world (Tockner et al. 2008). Yet in a growing number of river basins, water stress means that human and environmental needs cannot both be satisfied, necessitating difficult trade-offs when allocating finite water resources (Vörösmarty et al. 2010).

Increasingly, alternative approaches are being sought to optimize environmental benefits while minimizing environmental water allocations. In Australia's MurrayDarling Basin (MDB), one of the world's largest floodplain ecosystems affected by large-scale river regulation (Nilsson et al. 2005), engineering-based approaches to supplying water to floodplain wetlands are being used as a "water-efficient" method to achieve ecological goals without needing to reinstate overbank floods (Table 1; Pittock et al. 2013). Such approaches include inundating floodplains through pumping and diversion canals, and then controlling water movement on floodplains with levees, weirs, and regulators (Table 1). Similar large-scale infrastructure projects are also being considered in parts of Asia, such as China's Poyang Lake on the lower Yangtze River floodplain, which has experienced prolonged low water periods since construction of the Three Gorges Dam. These engineering infrastructure programs are broadly designed to create or maintain local flooding regimes (referred to here as "engineered floods") that mimic natural floodplain inundation patterns, but without the normal prerequisite of increased river discharge. They are therefore distinct from traditional environmental flow releases, which we refer to as "augmented floods". Engineered floods require floodplain infrastructure (eg 


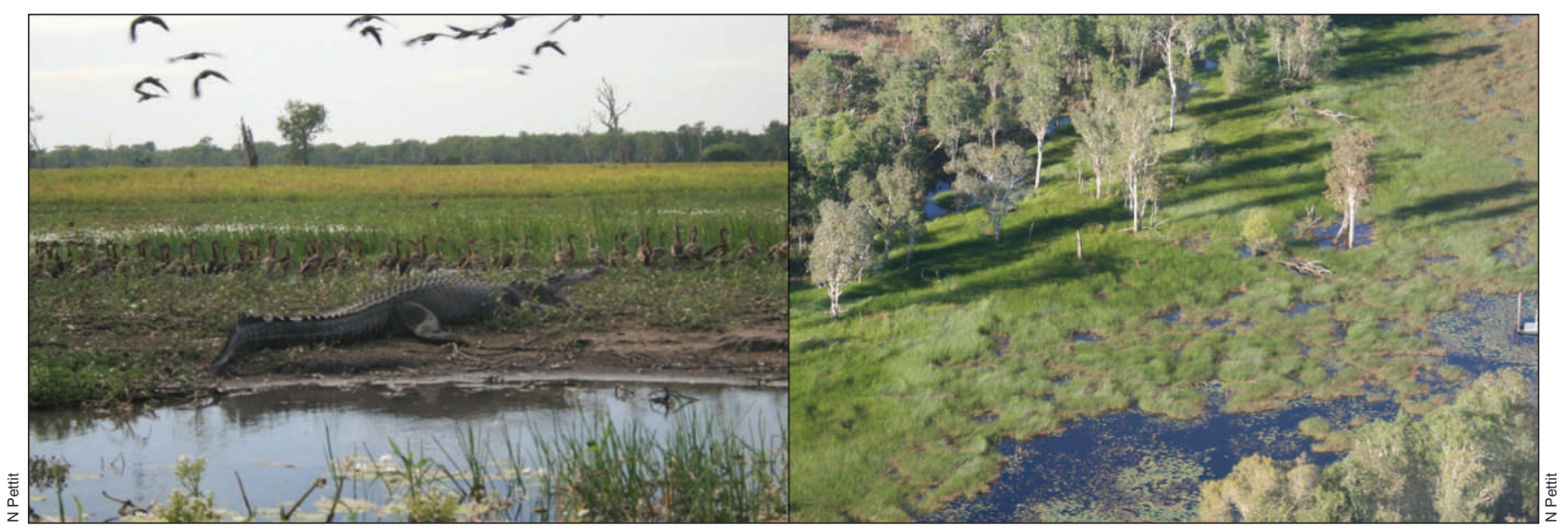

Figure 1. Productive floodplain environments such as those of Magela Creek in northern Australia depend on periodic flooding to deliver nutrients and sediment; such flooding also allows biota to move between the river channel and floodplain habitats.

levees and flood channels) that historically has been more widely used to prevent or limit inundation from natural floods. Such infrastructure is often aimed at protecting human assets and is now increasingly being considered for removal in some areas due to the high costs of repair, maintenance, and operation (Suddeth et al. 2010).

While the use of engineering infrastructure to prevent flooding may be most familiar, similar approaches have long been used to provide water to floodplains for agriculture. In Egypt, for instance, canals were used to divert floodwaters to the floodplain for irrigation as far back as the third millennium BCE (Hassan 1997), and managed inundation of "water meadows" for enhanced pasture growth in the low-lying floodplains of European rivers created productive wetlands for many centuries (Cook and Williamson 2007). However, the use of engineering structures to provide water to stressed floodplains solely for environmental benefits is a relatively new practice. For example, in the 1990s, sluice gates and channels were constructed to allow managed flooding from existing dams of the Senegal River to improve ecological and societal (eg traditional fishing and grazing) benefits (Duvail and Hamerlynck 2003). In the case of the MDB in Australia, various schemes were put in place to create engineered artificial floods (referred to locally as "environmental works and measures"), as a means of "watering" flood-dependent forests at risk of catastrophic mortality during a recent prolonged drought (Figure 2; MDBA 2011). As a result of the apparent short-term success of these efforts during the drought, the scope for delivery of engineered floods using floodplain infrastructure has now been widened. Increasingly, engineered flooding is being viewed as a potential alternative to more traditional landscape-scale, augmented flooding approaches for achieving ecological objectives in floodplain ecosystems (eg MDBA 2011). Similar examples from the Middle East, Asia, and North America have typically also been designed to provide water to support a dominant ecological value (mostly to provide waterbird habitat) rather than restoring broader floodplain ecosys- tem processes (Table 1; eg Galat et al. 1998).

Although engineered artificial floods are attractive for their potential water savings, the approach has garnered some criticism. In examining infrastructure plans in the MDB, Pittock et al. (2013) noted four areas of concern: the potential direct negative ecological effects, the institutional challenges involved in operating infrastructure effectively, the associated opportunity costs, and the potentially maladaptive outcomes linked to climate change. Here, we seek to expand on the ecological concerns raised by Pittock et al. (2013) within a broader global context, while also considering possible ways to mitigate negative impacts. We review the various ecological roles played by floods in sustaining floodplain river systems, highlight the potential risks and benefits of engineered artificial floods, and discuss ways to avoid the negative outcomes that might arise from their use.

Many aspects of engineered artificial flooding are at odds with the role of connectivity as a unifying concept emerging from flow-ecology research over the past 20

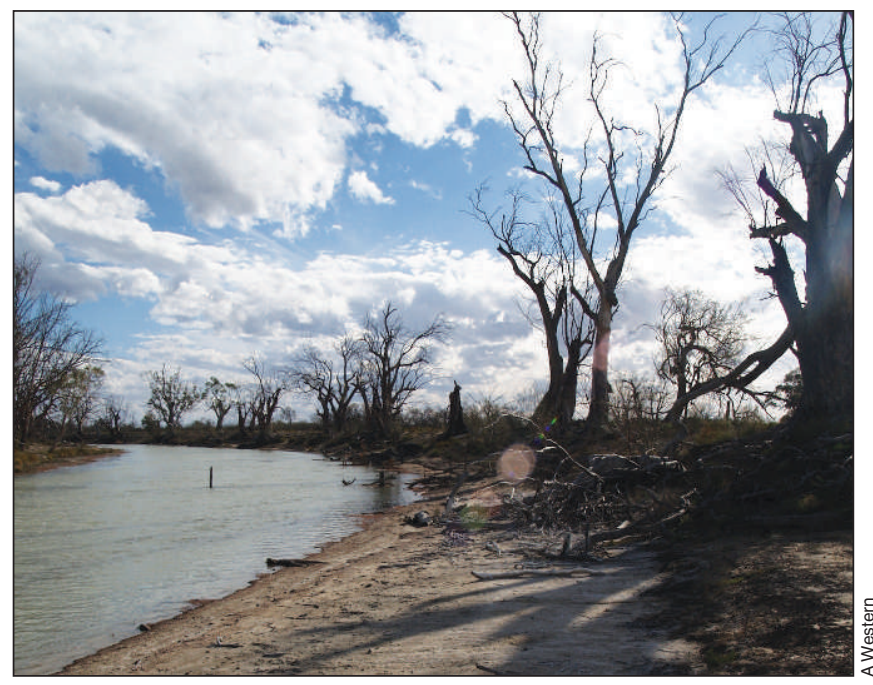

Figure 2. Dying red gums (Eucalyptus camaldulensis) due to salinization and reduced flood inundation are now commonly observed along large tracts of the lower Murray River floodplain. 
years - especially the roles of lateral and longitudinal linkages in supporting the flux of materials, energy, and biota between rivers and their floodplains (Junk et al. 1989; Tockner et al. 2000). Furthermore, it is not just the connectivity per se but the variable patterns within these connections, and hence the ecological fluxes, that largely dictate the mosaic of habitats and diversity of biota supported by healthy river-floodplain ecosystems (Ward et al. 1999; Naiman et al. 2008). Such diversity is a direct result of variability within flow regimes and the associated hydrological interactions with the landscape. While acknowledging that trade-offs are often necessary in water-stressed ecosystems, at present many indirect risks have not received sufficient attention in the planning, design, and operation of engineered artificial floods. In failing to consider these risks, the extent to which engineered floods may fail to support the broad range of ecosystem functions driven by overbank flows has also been overlooked. It is not our intention to criticize the approach in toto, but to expand on recent evidence regarding both the benefits and risks associated with engineered artificial floods. In particular, we discuss potential risk mitigation options, and identify some of the critical research needs, design requirements, and operational knowledge requirements that will help to avoid perverse ecological outcomes potentially resulting from engineered floods.

\section{The hydrologic case for engineered artificial flooding}

One of the major effects of river regulation is the reduction in floodplain inundation from small-to-medium floods (Galat et al. 1998). This outcome results in a suite

\begin{tabular}{|c|c|c|c|c|}
\hline Location & Engineering approach & Ecological target & Proposed or constructed & Reference \\
\hline Poyang Lake, China & Dam and sluice gates & $\begin{array}{l}\text { Increase seasonal wetland } \\
\text { flooding }\end{array}$ & Proposed & $\begin{array}{l}\text { www.china.org.cn/environment/2012- } \\
\text { 02/28/content_24747796.htm }\end{array}$ \\
\hline $\begin{array}{l}\text { Nebraska Rainwater } \\
\text { Basin wetlands, US }\end{array}$ & $\begin{array}{l}\text { Pumping of water } \\
\text { into wetlands }\end{array}$ & $\begin{array}{l}\text { Increase wetland area for } \\
\text { migratory birds }\end{array}$ & $\begin{array}{l}\text { Pumping and piping of } \\
\text { water since } 2003 ; \\
\text { clearing of sediments } \\
\text { from wetlands and } \\
\text { infilling drainage pits }\end{array}$ & $\begin{array}{l}\text { www.fws.gov/refuge/rainwater_basin } \\
\text { wmd }\end{array}$ \\
\hline Missouri River, US & $\begin{array}{l}\text { Managed flooding; } \\
\text { levees; combined } \\
\text { active and passive } \\
\text { management }\end{array}$ & $\begin{array}{l}\text { Improve bird and fish } \\
\text { breeding }\end{array}$ & $\begin{array}{l}\text { Re-operation of existing } \\
\text { structures }\end{array}$ & Galat et al. (1998) \\
\hline $\begin{array}{l}\text { Everglades } \\
\text { Restoration, US }\end{array}$ & $\begin{array}{l}\text { Canals; levees; water- } \\
\text { control structures }\end{array}$ & $\begin{array}{l}\text { Restore the South Florida } \\
\text { ecosystem and provide for } \\
\text { other water resource needs }\end{array}$ & $\begin{array}{l}\text { Under construction } \\
\text { (expected completion } \\
\sim 30 \text { years) }\end{array}$ & www.evergladesplan.org \\
\hline $\begin{array}{l}\text { Gunbower- } \\
\text { Koondrook- } \\
\text { Perricoota Forest, } \\
\text { Murray River, } \\
\text { Australia }\end{array}$ & $\begin{array}{l}\text { Complex system of } \\
\text { regulators, constructed } \\
\text { channels, weirs, and } \\
\text { levee banks }\end{array}$ & $\begin{array}{l}\text { Improve the management } \\
\text { and timing of floodwaters } \\
\text { to enhance colonial } \\
\text { waterbird and native fish } \\
\text { breeding and the health of } \\
\text { river red gum forests }\end{array}$ & Approved & MDBA (20II) \\
\hline $\begin{array}{l}\text { Chowilla Floodplain, } \\
\text { Murray River, } \\
\text { Australia }\end{array}$ & $\begin{array}{l}\text { Pumping of water into } \\
\text { wetlands; injection of } \\
\text { water into unconfined } \\
\text { groundwater; } \\
\text { regulators to enhance } \\
\text { local flooding }\end{array}$ & $\begin{array}{l}\text { Improve health of riparian } \\
\text { and floodplain forests }\end{array}$ & $\begin{array}{l}\text { Under construction } \\
\text { (expected completion } \\
\text { in 2014) }\end{array}$ & Holland et al. (2009) \\
\hline $\begin{array}{l}\text { Hattah Lakes, } \\
\text { Murray River, } \\
\text { Australia }\end{array}$ & $\begin{array}{l}\text { Pumping of water into } \\
\text { wetlands; regulators } \\
\text { to hold environmental } \\
\text { water }\end{array}$ & $\begin{array}{l}\text { Improve health of riparian } \\
\text { and floodplain forests; } \\
\text { improve aquatic habitat }\end{array}$ & $\begin{array}{l}\text { Some structures in } \\
\text { place, others planned }\end{array}$ & MDBA (20II) \\
\hline $\begin{array}{l}\text { Lower Lakes, } \\
\text { Murray River, } \\
\text { Australia }\end{array}$ & Temporary levee & $\begin{array}{l}\text { Limit exposure of acid } \\
\text { sulfate soils and reduce } \\
\text { the risk of water-body } \\
\text { acidification }\end{array}$ & Temporary structures & Bice and Zampatti (20II) \\
\hline $\begin{array}{l}\text { Azraq wetlands, } \\
\text { Jordan }\end{array}$ & $\begin{array}{l}\text { Pumping of water into } \\
\text { wetlands }\end{array}$ & $\begin{array}{l}\text { Increase wetland area for } \\
\text { migratory birds }\end{array}$ & $\begin{array}{l}\text { Pumping of water into } \\
\text { wetlands since } 1994\end{array}$ & $\begin{array}{l}\text { www.rscn.org.jo/RSCN/HelpingNature/ } \\
\text { ProtectedAreas/AzraqWetlandReserve/ } \\
\text { tabid/98/Default.aspx }\end{array}$ \\
\hline $\begin{array}{l}\text { Arkansas "greentree } \\
\text { reservoirs", US }\end{array}$ & $\begin{array}{l}\text { Levees, locks, and weirs } \\
\text { for impounding water } \\
\text { around riparian } \\
\text { hardwood forests }\end{array}$ & $\begin{array}{l}\text { Increase habitat and } \\
\text { foraging for waterbirds }\end{array}$ & Constructed & King et al. (1998) \\
\hline
\end{tabular}




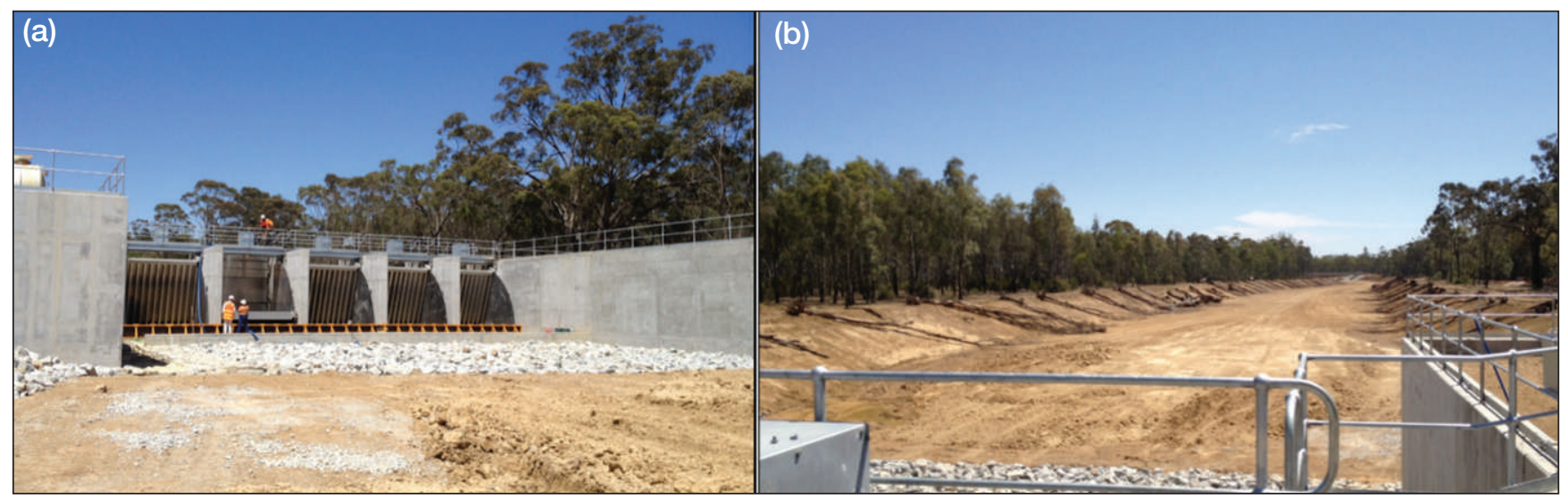

Figure 3. Examples of large-scale works associated with the creation of artificial floods. (a) Control gates on the Edward River, an anabranch (side channel) of the Murray River, and (b) a diversion channel (Torrumbarry Cutting) in Koondrook-Perricoota Forest on the Murray River floodplain in southeastern Australia.

of direct and indirect effects on floodplains and in rivers, including increased mortality of floodplain vegetation (Cunningham et al. 2009), loss of floodplain wetlands, reduced river-floodplain productivity (Bayley 1991), and loss of access to breeding and rearing habitats for fish and other riverine biota. A key goal of environmental flow programs in large river systems has thus been to restore some of the natural flood pulses that are considered to have the greatest ecological or geomorphological effects. One of the best known examples is in the Colorado River in the southwestern US, where managed floods have been used to target geomorphic processes and restore or maintain populations of key fish species (Valdez et al. 2001).

However, in many river systems - particularly low-gradient rivers with extensive floodplains - large reservoirs are located in the headwaters, often hundreds of kilometers from the floodplain reaches targeted by environmental flows. Therefore, augmented flooding using run-ofriver environmental flows is often difficult without posing a flood risk to nearby human populations and associated infrastructure, exceeding the design capacity of outflow pipes of upstream storages, exceeding natural geomorphic flow-regulating features of the river (Holland et al. 2009), and exceeding volumes of available water after competing uses are taken into account. These are the systems where engineering approaches are proposed or are in use (Table 1). The key aim of engineering works is thus to achieve critical environmental flow targets (defined in terms of the timing, duration, and frequency of floodplain inundation) using less water; this can be achieved by either actively pumping or passively diverting and trapping water on floodplains or within specific wetlands through weirs, levees, channels, and flow regulators, as opposed to relying on overbank or run-of-river floods (Figure 3). Although the associated water efficiency of these engineering approaches is well recognized, they are expensive to construct, maintain, and operate, and have limited spatial coverage; furthermore, to a large extent, their ecological effectiveness has yet to be documented (Pittock et al. 2013).

\section{Engineered floods: risks and benefits}

The ecological risks and benefits of engineered artificial flooding can be divided into three major categories: (1) those relevant to floodplain specialist biota, (2) those affecting the fluxes of materials and energy between rivers and their floodplains, and (3) those affecting the movement of biota between river and floodplain habitats.

\section{Floodplain specialist biota}

The initial objective of engineered flooding programs in the MDB was to prevent the mortality of floodplain river red gum (Eucalyptus camaldulensis) forests that were at risk as a result of prolonged drought and rising saline water tables (Figure 2; MDBA 2011). Where implemented, the approach proved extremely effective, with moist soils after re-watering helping to promote tree survival, germination, and recruitment (Jensen et al. 2008). Furthermore, as with natural flooding, artificially watering wetlands and floodplains increases the amount of standing water and enhances the persistence of floodplain wetlands, which are important habitats for aquatic plants, amphibians, waterbirds, and fish. Providing habitat for waterbird breeding is a major driver for managed run-of-river floods, particularly in the case of species that require long periods of flooding and semi-permanent floodplain wetlands to breed (Kingsford and Auld 2005). Globally, numerous engineered floods have been implemented primarily to increase available habitat for waterbirds (Table 1). Engineered floods are therefore likely to be an appealing option in regions where vegetation condition is very poor, bird breeding has ceased or declined, and natural floods no longer occur.

The application of engineered floods, however, is not without risk to floodplain biota. Increasing floodplain inundation in areas of shallow saline water tables provides only a partial solution to poor floodplain tree health if not accompanied by lowering of the water table (Holland et al. 2009). Engineering structures may even 
exacerbate salinity problems by artificially maintaining high water levels in the river channel without coincident floodplain flushing, thereby preventing saline groundwater from draining into the river. In the US, the managed inundation of hardwood forests by "greentree reservoirs" to provide waterbird habitat has also driven these forests toward a more water-tolerant community that may now provide fewer food resources for key waterbird species (King et al. 1998).

\section{Material and energy exchanges}

For many riverine processes, the hydrodynamics of flooding are important (Steiger and Gurnell 2002; Ahearn et al. 2006; Howitt et al. 2007). These hydrodynamic characteristics clearly have a major bearing on the patterns of sediment, nutrient, energy, and biotic exchange - in terms of what leaves the river (eg deposition and erosion of sediments; Steiger and Gurnell 2002), what is exchanged on the floodplain (eg liberation and transformation of carbon [C] and nutrients; Valett et al. 2005; Baldwin et al. 2012), and what is returned to the river (Junk et al. 1989).

Engineered floods pose the greatest ecological risks because of the alteration or loss of these exchanges. Although there are scant data on the influence of engineered floods on the flux of sediments and most nutrients, the impacts on C fluxes have been well studied. In particular, prolonged floodplain inundation with only limited exchange of water from the river can induce hypoxic blackwater events, which are driven by the leaching and subsequent microbial respiration of $\mathrm{C}$ from terrestrial leaf litter (Valett et al. 2005; Howitt et al. 2007). While floodplain terrestrial inputs are an important source of $\mathrm{C}$ and nutrients to the river system (eg Junk et al. 1989), and despite the fact that many lowland fish species exhibit a high degree of tolerance to hypoxia (McNeil and Closs 2007; McMaster and Bond 2008), these blackwater events can cause fish kills that have catastrophic short- and long-term effects on fish and crayfish populations (King et al. 2012). Even though such events also occur naturally, the risks are greatly elevated where water is ponded behind barriers on the floodplain with limited exchange, thereby increasing the floodplain residency time (see Figure 4; Galat et al. 1998; Valett et al. 2005; Baldwin et al. 2011), and where the reduced frequency of floodplain inundation events in regulated rivers allows greater litter accumulation (Howitt et al. 2007). The negative impacts of such events can extend far downstream if sufficient hypoxic blackwater enters the river channel (King et al. 2012).

In contrast to the threats from blackwater events, floodplain-derived $\mathrm{C}$ is also an important source of energy that supports production in floodplain rivers (Zeug and Winemiller 2008; Hladyz et al. 2010; Jardine et al. 2012). In heavily regulated rivers, the loss of floodplain inundation events can create an energy bottleneck that limits the carrying capacity of higher trophic levels (Naiman and Turner 2000), which can have strong social and economic implications in terms of lost food production (Orr et al. 2012). Overcoming such bottlenecks may involve restoring food webs and their associated energy pathways (Naiman et al. 2012), including the flux of energy back to the river, as dissolved organic $\mathrm{C}$ becomes incorporated into the tissue of biota that utilize floodplain nutrients (Jardine et al. 2012). The avoidance of blackwater events and the maintenance of energy fluxes depend on the hydrodynamics of floodplain inundation, including the duration of inundation and water residency time, and it is still unclear whether these processes can be adequately mimicked by the types of engineering works being considered and, if so, under what operating strategies.

\section{Biotic movements and connections}

In addition to floodplain processes, many in-channel ecological processes depend on flood events as a trigger. Rising river levels assist in dispersing plant propagules and triggering germination (Pettit and Froend 2001), promoting fish spawning and recruitment (King et al. 2009), promoting fish movement (O'Connor et al. 2005), and cueing some colonial waterbirds to breed (Kingsford and Auld 2005). Some species of fish also move out of the river channel to breed (Fry 2002; Barko et al. 2006), but such movements can be hindered or halted by water-control structures (Jones and Stuart 2008). Fish and invertebrates that survive being passed through pumps further risk becoming trapped on the floodplain and not returning to the river channel (Figure 5; Jenkins and Boulton 2003; Jones and Stuart 2008). There are similar concerns that the proposed weir between Poyang Lake and the Yangtze River will preclude movement of Yangtze finless porpoises (Neophocaena phocaenoides), which are highly imperiled in the wild and currently move between these habitats in search of food (Wang 2009).

As well as promoting reduced connectivity, altered hydraulic regimes may favor spawning and recruitment of exotic fish species, such as common carp (Bice and Zampatti 2011), and could also benefit introduced weed species (Catford et al. 2011). Consequently, assemblage structure and diversity may be substantially modified, thereby promoting dominance of exotic species and altering river-floodplain structure and function.

\section{Making engineered floods work}

Reliance on engineered floods to inundate floodplains clearly carries a mix of potential benefits and risks. It is likely that some ecological processes are simply incompatible with some methods of inundation, because those processes depend either on the hydrodynamics of flooding (eg water residence time) or on the ways that rivers and their floodplains are connected. For example, pumping is wholly incompatible with the movement of adult 

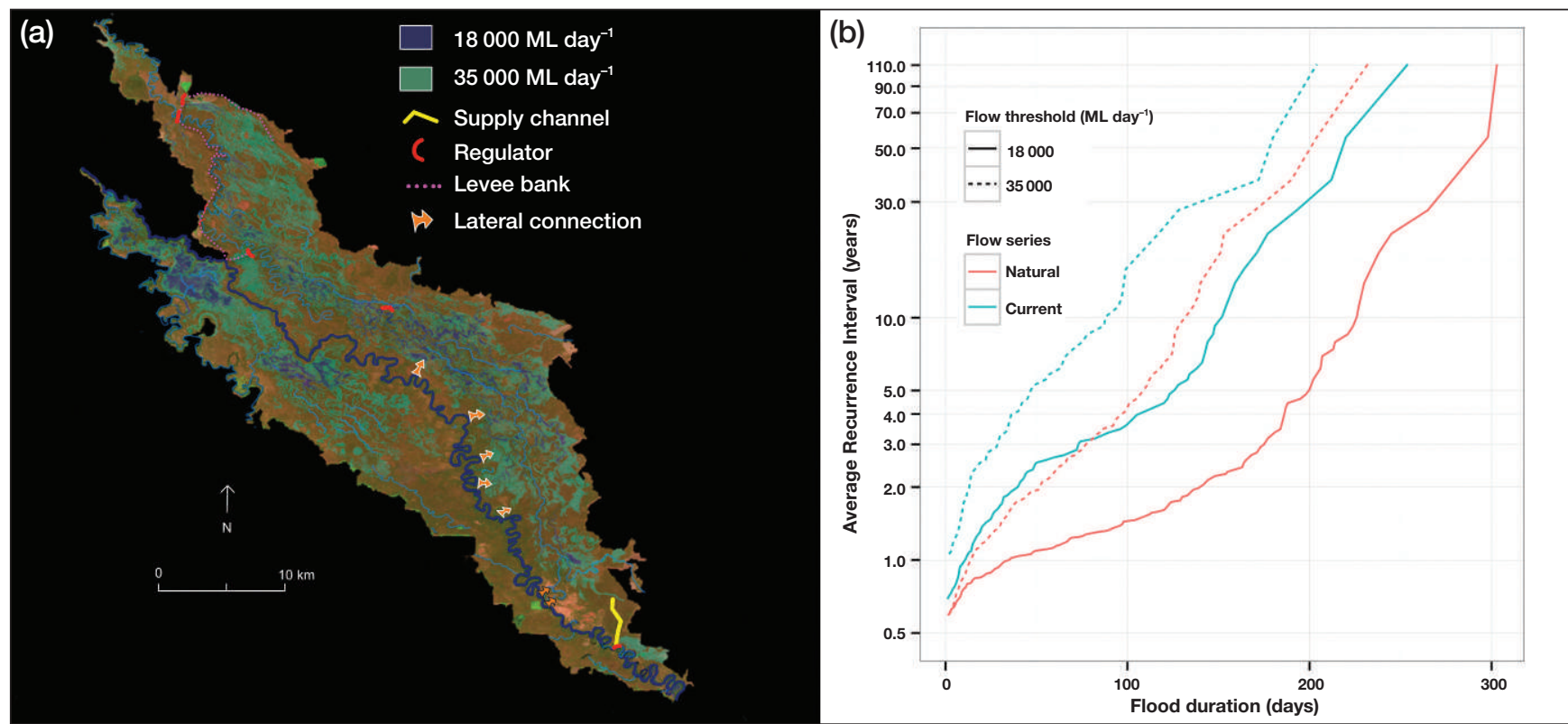

Figure 4. Koondrook-Perricoota (KP) Forest forms part of the second largest river red gum forest in southeastern Australia and is listed as a wetland of international importance under the Ramsar Convention. It also supports several important waterbird colonies and populations of nationally threatened plants and fish. The forest is dissected by numerous small channels, which begin to flow from the main river at a discharge of approximately 18000 million liters per day $\left(\mathrm{ML} \mathrm{day}{ }^{-1}\right)$ in the Murray River (a). At higher flows, water spills into the forest at various points along the river; at flows between 30000 and $35000 \mathrm{ML}$ day $^{-1}$ the area of forest inundated rises to between $30 \%$ and $50 \%$. The frequency and duration of forest inundation has been greatly reduced by river regulation (b), causing major forest dieback along the Murray River (eg Figure 2). A program of works is presently underway to construct a delivery channel (Torrumbarry Cutting) at the head of KP Forest, and a series of downstream regulators and levee banks to maintain high water levels within the forest (a). These works will allow water to enter the forest at river flows of less than $15000 \mathrm{ML}$ day ${ }^{-1}$, greatly reducing water demand. However, concerns have been raised that the artificial ponding of water will lead to blackwater events in the forest and the main channel of the river (Baldwin et al. 2011). Connection at lower flows will also reduce lateral connectivity for species, including various fish and amphibians. Opportunities to mitigate these impacts include the modification/reoperation of downstream regulators to reduce ponding and timing flooding to coincide with cooler months. Despite considerable modeling, the extent to which long-term management objectives can be met with reduced flows remains uncertain, highlighting the need for ongoing ecosystem monitoring.

fish onto floodplains, although this can be used to reduce the spread of exotic species and favor small-bodied fish (Vilizzi et al. 2012). In other cases, appropriate management of water infrastructure could mitigate some of the risks by replicating natural hydrodynamic variability (Figure 5; Table 2). For instance, blackwater events are relatively well understood, and are probably best managed by ensuring that water is not ponded onto floodplains for too long; floodplains are regularly inundated to prevent a buildup of organic material; flooding occurs during periods of cooler water temperatures (when microbial decomposition rates will be lower); or where long inundation periods are required (eg for bird breeding), an ongoing exchange of water between the river and the floodplain is established (Valett et al. 2005; King et al. 2012). If done well, this can facilitate the transfer of floodplain-derived $\mathrm{C}$ and nutrients back to the river channel without risks to in-channel and floodplain biota. This, of course, can be achieved only at the cost of additional water relative to that used when ponding is maintained for longer durations (Figure 4).

While effects within areas targeted for water delivery have received much attention, another major consequence of engineered floods is that higher flood frequen- cies are restored only to isolated sections of the floodplain (MDBA 2011; Pittock et al. 2013). This has important consequences in terms of the extent to which such flooding contributes to increased riverine and floodplain production at large spatial scales, which can be critical in supporting the ecological and socioeconomic value of local and downstream fisheries (Bayley 1991; Opperman et al. 2010). Conversely, a potential benefit of engineered floods is the ability to target flooding toward high-value ecosystems while reducing the likelihood of inundating agricultural land and human infrastructure. This can have indirect benefits to ecosystems, for example by reducing the export of toxic chemicals from agriculture (Beketov et al. 2013). Clearly, modifying the hydraulic parameters of artificial floods (ie their velocity, magnitude, and residency) will depend on floodplain topology and priority conservation values and so may vary on a case-by-case (or even on an event-by-event) basis. This will require flexibility in delivery and managing expectations, for instance accepting that not all ecological targets may be achieved.

The effectiveness of alternative management options hinges on the specific ecosystem objectives being sought by means of floodplain reconnections. In many water- 


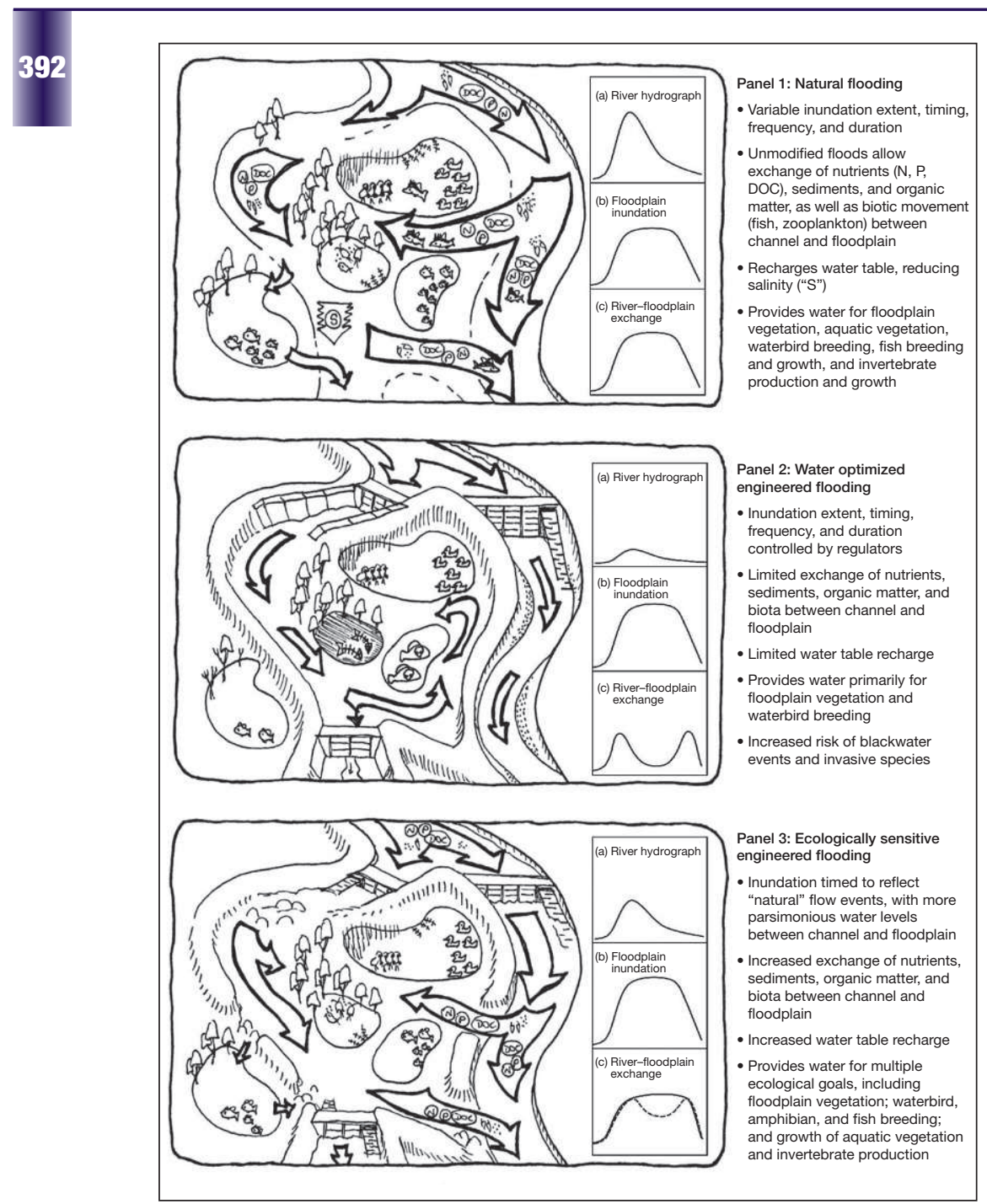

Figure 5. Key differences in the ecological processes associated with natural floods, including flow-optimized and carefully designed floodplain reconnection strategies. The inset panels illustrate variations in channel and floodplain hydrology under each scenario.

stressed regions, particularly where stresses will be exacerbated by climate change and further development pressure, engineered floods are increasingly seen as the only option once governments consider the various ecological, social, and economic values at stake. Where this is the case, it must be recognized that only a limited number of ecological objectives are likely to be achievable. These objectives need to be articulated and accepted by all stakeholders, and engineered floods must be monitored for their effectiveness and modified (in either their design or operation) when necessary. Engineered floods and their associated infrastructure requirements should also be viewed and implemented in the broader context of floodplain restoration requirements at larger spatial scales (eg catchment/basin), and their benefits considered within a temporal context (eg their role in emergency watering of valuable assets versus meeting long-term hydrological regime requirements). Artificial watering via engineering approaches should not be expected to achieve equivalent ecological responses to those that natural floods, or indeed augmented floods, would provide.

\section{A new conceptual framework for evaluating environmental flows}

Engineered floods have emerged as a seemingly practical solution to achieving environmental flow targets in water-stressed systems. Historically, targets for floodplain inundation have been defined in terms of hydrologic characteristics (eg the timing, frequency, and duration of flood events) rather than in terms of hydrodynamics (eg residency time, velocity profiles, variable flow paths, and patterns of connection with the river channel). However, in many cases these hydrodynamic aspects of floods and the associated mosaic of inundation depths, durations, and flow velocities drive important physical and biological responses (Ward et al. 1999). The existing conceptual framework has been sufficient when floods are delivered as run-of-river events (either natural or augmented floods). Yet the growing use of engineered floods may warrant inclusion of additional hydrodynamic descriptors within the conceptual framework used to inform and set environmental flows, especially where targets require floodplain reconnection. This would facilitate more formal and thorough evaluation of the types of risks and trade-offs that we have identified (Table 2), but will also entail additional hydrodynamic modeling.

\section{- Conclusions}

Engineered floods are a potentially efficient way of watering floodplains to achieve environmental objectives with limited volumes of water. Their use is expanding rapidly in some regions to support environmental flow delivery, and is likely to expand elsewhere in the future as a result of increasing water scarcity. Nevertheless, engineered floods pose potential ecological risks associated with the disruption of natural river-floodplain and upstreamdownstream linkages, even though this approach may provide the only means of trying to mimic historical inundation patterns in some floodplains and wetlands without substantially increasing the volume of water allocated to environmental flows. Adopting engineered floods as a strategy will necessarily entail a trade-off in terms of the water savings and specific environmental benefits that environmental flows might otherwise achieve. There is a crucial need for more rigorous research on the effectiveness and risks of this approach, and the various forms of infrastructure by which engineered floods might be created, particularly focusing on the infrastructure required to optimize fluxes to and from the floodplain. Broader research on floodplain restoration more generally is also warranted (Lake 2012). A thorough 
Table 2. Potential ecological trade-offs associated with different methods of managing water to achieve artificial floodplain inundation events

\begin{tabular}{|c|c|c|c|c|}
\hline Engineering method & Effects & Benefits & Challenges & Options for mitigation \\
\hline $\begin{array}{l}\text { Water delivered } \\
\text { to floodplains via } \\
\text { pumping }\end{array}$ & $\begin{array}{l}\text { Floodplain } \\
\text { inundation to } \\
\text { mimic natural } \\
\text { floods }\end{array}$ & $\begin{array}{l}\text { Provides water to floodplain } \\
\text { vegetation; promotes } \\
\text { germination; replenishes } \\
\text { floodplain wetlands; } \\
\text { provides opportunities } \\
\text { for bird breeding }\end{array}$ & $\begin{array}{l}\text { Mortality of fish (including larvae } \\
\text { and eggs) via damage incurred by } \\
\text { being passively sucked through } \\
\text { pump; pumps represent a } \\
\text { barrier to dispersal by fish and } \\
\text { other large taxa; natural flow } \\
\text { pathways lost; no access to } \\
\text { critical habitat (eg breeding, } \\
\text { rearing, feeding) for fish and } \\
\text { turtles; minor lateral export } \\
\text { of sediment and nutrients }\end{array}$ & $\begin{array}{l}\text { Larger intakes for pumps to reduce water } \\
\text { pressure and mortality of eggs, zoo- } \\
\text { plankton, etc; screen pump intakes and/or } \\
\text { limit extraction to non-spawning periods; } \\
\text { limit the use of pumps to extreme dry } \\
\text { periods and rely on natural overbank floods } \\
\text { at other times }\end{array}$ \\
\hline $\begin{array}{l}\text { Water delivered } \\
\text { to floodplains via } \\
\text { constructed } \\
\text { channels }\end{array}$ & $\begin{array}{l}\text { Floodplain } \\
\text { inundation to } \\
\text { mimic overland } \\
\text { flows }\end{array}$ & $\begin{array}{l}\text { Provides water to floodplain } \\
\text { vegetation and promotes } \\
\text { germination; replenishes } \\
\text { floodplain wetlands; } \\
\text { provides opportunities } \\
\text { for bird breeding; some } \\
\text { access to floodplain by } \\
\text { riverine biota }\end{array}$ & $\begin{array}{l}\text { Natural flow pathways lost; } \\
\text { reduced access to critical } \\
\text { habitat (eg breeding, rearing, } \\
\text { feeding) for fish and turtles; } \\
\text { reduced lateral export of } \\
\text { sediment and nutrients }\end{array}$ & $\begin{array}{l}\text { Use existing natural entry points such as } \\
\text { off-take channels where fish may be } \\
\text { naturally cued to move; channel design } \\
\text { should incorporate "rough" surfaces to } \\
\text { reduce velocities and turbulence to aid } \\
\text { movement both in and out during } \\
\text { connection; plan diversions to coincide with } \\
\text { minor (in-channel) floods to increase } \\
\text { sediment and nutrient export }\end{array}$ \\
\hline $\begin{array}{l}\text { Artificial ponding } \\
\text { of water on } \\
\text { floodplain using } \\
\text { down-slope } \\
\text { infrastructure } \\
\text { (weirs, control } \\
\text { gates, and levees) }\end{array}$ & $\begin{array}{l}\text { Increases } \\
\text { inundation } \\
\text { duration }\end{array}$ & $\begin{array}{l}\text { Provides inundation duration } \\
\text { sufficient for germination } \\
\text { and breeding; increased } \\
\text { floodplain productivity after } \\
\text { mobilization of fine } \\
\text { particulate organic matter } \\
\text { and organic C }\end{array}$ & $\begin{array}{l}\text { Water-quality degradation (eg } \\
\text { hypoxic blackwater, cyano- } \\
\text { bacterial blooms) and potential } \\
\text { fish and crayfish kills on } \\
\text { floodplain and in river channel; } \\
\text { reduced energy subsidies from } \\
\text { floodplain back to the river } \\
\text { channel; loss of diversity of flow } \\
\text { types (habitat types) in forest } \\
\text { wetland systems, leading to } \\
\text { decline in species richness and } \\
\text { productivity of micro- and } \\
\text { macroinvertebrates and fish; } \\
\text { entrapment of fish and turtles }\end{array}$ & $\begin{array}{l}\text { Time inundation events to occur during } \\
\text { cooler periods (reduced risk of water- } \\
\text { quality decline); prevent buildup of organic } \\
\text { matter through regular inundation; } \\
\text { manipulate water levels to promote some } \\
\text { heterogeneity in velocities and depths; } \\
\text { maintain sufficient returns to increase } \\
\text { energy subsidies and biological } \\
\text { connectivity from the floodplain to } \\
\text { the river }\end{array}$ \\
\hline
\end{tabular}

assessment of the likelihood that engineered floods will achieve their intended ecological goals should be undertaken before the necessary infrastructure is constructed. This should include consideration of other floodplain interventions (eg levee removal and agricultural retirement) that may also be required (Lake 2012). The effectiveness of engineered floods in achieving ecological goals should also be further assessed using rigorous monitoring programs that take into account the difficulties of monitoring environmental flow outcomes in regulated river systems (Konrad et al. 2011). To this end we encourage dialogue among water managers, engineers, ecologists, and other stakeholders in examining the ecological and socioeconomic risks, trade-offs, and opportunities in both the construction and operation of engineered-flood-associated infrastructure, to ensure that the range of potential tradeoffs is fully understood and explored before further major investment occurs.

\section{Acknowledgements}

This work was supported by the Australian Centre for Ecological Analysis and Synthesis (ACEAS), a facility of the Australian Government-funded Terrestrial Ecosystem Research Network (www.tern.org.au), a network estab- lished under the National Collaborative Research Infrastructure Strategy, through the Department of Innovation, Industry, Science, and Research. We thank ACEAS, and A Specht in particular. A Arthington, R Watts, B Downes, C Matthei, S Lake, and J Lyon also provided useful comments on earlier drafts of the manuscript. The Commonwealth Scientific and Industrial Research Organisation (CSIRO) kindly provided access to the RiMFIM model outputs.

\section{References}

Ahearn DS, Viers JH, Mount JF, and Dahlgren RA. 2006. Priming the productivity pump: flood pulse driven trends in suspended algal biomass distribution across a restored floodplain. Freshwater Biol 51: 1417-33.

Baldwin DS, Rees GN, Wilson JS, et al. 2012. Provisioning of bioavailable carbon between the wet and dry phases in a semiarid floodplain. Oecologia 172: 539-50.

Baldwin DS, Williams J, and Whitworth K. 2011. Understanding blackwater generated from the Koondrook-Perricoota Forest. Final Report prepared for the Murray-Darling Basin Authority by The Murray-Darling Freshwater Research Centre. MDFRC Publication 17/2011. www.mdba.gov.au/kid/files/1947-Koond rook-Perricoota-Blackwater-Baldwin_et_al_2011.pdf. Viewed 1 Aug 2013.

Barko V, Herzog D, and O'Connell M. 2006. Response of fishes to floodplain connectivity during and following a 500-year flood 
event in the unimpounded upper Mississippi River. Wetlands 26: 244-57.

Bayley PB. 1991. The flood pulse advantage and the restoration of river-floodplain systems. Regul River 6: 75-86.

Beketov MA, Kefford BJ, Schäfer RB, and Liess M. 2013. Pesticides reduce regional biodiversity of stream invertebrates. P Natl Acad Sci USA 110: 11039-43.

Bice CM and Zampatti BP. 2011. Engineered water level management facilitates recruitment of non-native common carp, Cyprinus carpio, in a regulated lowland river. Ecol Eng 37: 1901-04.

Catford JA, Downes BJ, Gippel CJ, and Vesk PA. 2011. Flow regulation reduces native plant cover and facilitates exotic invasion in riparian wetlands. J Appl Ecol 48: 432-42.

Cook $\mathrm{H}$ and Williamson T. 2007. Water meadows: history, ecology and conservation. Macclesfield, UK: Windgather Press.

Cunningham S, Mac Nally R, Read J, et al. 2009. A robust technique for mapping vegetation condition across a major river system. Ecosystems 12: 207-19.

Duvail S and Hamerlynck O. 2003. Mitigation of negative ecological and socio-economic impacts of the Diama Dam on the Senegal River Delta wetland (Mauritania), using a model based decision support system. Hydrol Earth Syst Sc 7: 133-46.

Fry B. 2002. Stable isotopic indicators of habitat use by Mississippi River fish. J N Am Benthol Soc 21: 676-85.

Galat DL, Fredrickson LH, Humburg DD, et al. 1998. Flooding to restore connectivity of regulated, large-river wetlands. BioScience 48: 721-33.

Hassan FA. 1997. The dynamics of a riverine civilization: a geoarchaeological perspective on the Nile Valley, Egypt. World Archaeol 29: 51-74.

Hladyz S, Nielsen DL, Suter PJ, and Krull ES. 2010. Temporal variations in organic carbon utilization by consumers in a lowland river. River Res Appl 28: 513-28.

Holland KL, Charles AH, Jolly ID, et al. 2009. Effectiveness of artificial watering of a semi-arid saline wetland for managing riparian vegetation health. Hydrol Process 23: 3474-84.

Howitt JA, Baldwin DS, Rees GN, and Williams JL. 2007. Modelling blackwater: predicting water quality during flooding of lowland river forests. Ecol Model 203: 229-42.

Jardine TD, Pusey BJ, Hamilton SK, et al. 2012. Fish mediate high food web connectivity in the lower reaches of a tropical floodplain river. Oecologia 168: 829-38.

Jenkins KM and Boulton AJ. 2003. Connectivity in a dryland river: short-term aquatic microinvertebrate recruitment following floodplain inundation. Ecology 84: 2708-23.

Jensen AE, Walker KF, and Paton DC. 2008. The role of seedbanks in restoration of floodplain woodlands. River Res Appl 24: 632-49.

Jones MJ and Stuart IG. 2008. Regulated floodplains - a trap for unwary fish. Fisheries Manag Ecol 15: 71-79.

Junk WJ, Bayley PB, and Sparks RE. 1989. The flood pulse concept in river-floodplain systems. Can Spec Publ Fish Aquat Sci 106: $110-27$.

King AJ, Tonkin ZD, and Lieshcke J. 2012. Short-term effects of a prolonged blackwater event on aquatic fauna in the Murray River, Australia: considerations for future events. Mar Freshwater Res 63: 576-86.

King AJ, Tonkin ZD, and Mahoney J. 2009. Environmental flow enhances native fish spawning and recruitment in the Murray River, Australia. River Res Appl 25: 1205-18.

King SL, Allen JA, and McCoy JW. 1998. Long-term effects of a lock and dam and greentree reservoir management on a bottomland hardwood forest. Forest Ecol Manag 112: 213-26.

Kingsford RT and Auld KM. 2005. Waterbird breeding and environmental flow management in the Macquarie Marshes, arid Australia. River Res Appl 21: 187-200.

Konrad CP, Olden JD, Lytle DA, et al. 2011. Large-scale flow experiments for managing river systems. BioScience 61: 948-59.

Lake PS. 2012. Flows, floods, floodplains and river restoration. Ecol Manag Restor 13: 210-11.
McMaster D and Bond NR. 2008. A field and experimental study on the tolerances of fish to Eucalyptus camaldulensis leachate and low dissolved oxygen concentrations. Mar Freshwater Res 59: $177-85$.

McNeil DG and Closs G. 2007. Behavioural responses of a southeast Australian floodplain fish community to gradual hypoxia. Freshwater Biol 52: 412-20.

MDBA (Murray-Darling Basin Authority). 2011. The living Murray story - one of Australia's largest river restoration projects. Canberra, Australia: MDBA.

Naiman RJ and Turner M. 2000. A future perspective on North America's freshwater ecosystems. Ecol Appl 10: 958-70.

Naiman RJ, Alldredge JR, Beauchamp DW, et al. 2012. Developing a broader scientific foundation for river restoration. P Natl Acad Sci USA 109: 21201-07.

Naiman RJ, Latterell JJ, Pettit NE, and Olden JD. 2008. Flow variability and the biophysical vitality of river systems. C R Geosci 340: 629-43.

Nilsson C, Reidy CA, Dynesius M, and Revenga C. 2005. Fragmentation and flow regulation of the world's large river systems. Science 308: 405-08.

O'Connor JP, O'Mahony DJ, and O'Mahony JM. 2005. Movements of Macquaria ambigua, in the Murray River, southeastern Australia. J Fish Biol 66: 392-403.

Opperman JJ, Luster R, McKenney BA, et al. 2010. Ecologically functional floodplains: connectivity, flow regime, and scale. $J$ Am Water Resour As 46: 211-26.

Orr S, Pittock J, Chapagain A, and Dumaresq D. 2012. Dams on the Mekong River: lost fish protein and the implications for land and water resources. Glob Environ Change 22: 925-32.

Pettit N and Froend R. 2001. Availability of seed for recruitment of riparian vegetation: a comparison of a tropical and a temperate river ecosystem in Australia. Aust J Bot 49: 515-28.

Pittock J, Finlayson CM, and Howitt J. 2013. Beguiling and risky: "environmental works and measures" for wetland conservation under a changing climate. Hydrobiologia 708: 111-31.

Steiger J and Gurnell AM. 2002. Spatial hydrogeomorphological influences on sediment and nutrient deposition in riparian zones: observations from the Garonne River, France. Geomorphology 49: 1-23.

Suddeth RJ, Mount J, and Lund JR. 2010. Levee decisions and sustainability for the Sacramento-San Joaquin Delta. San Fran Estuary Watershed Sci 8: 1-23.

Tockner K, Bunn S, Gordon C, et al. 2008. Flood plains: critically threatened ecosystems. In: Polunin NVC (Ed). Aquatic ecosystems: trends and global prospects. Cambridge, UK: Cambridge University Press.

Tockner K, Malard F, and Ward JV. 2000. An extension of the flood pulse concept. Hydrol Process 14: 2861-83.

Valdez RA, Hoffnagle TL, McIvor CC, et al. 2001. Effects of a test flood on fishes of the Colorado River in Grand Canyon, Arizona. Ecol Appl 11: 686-700.

Valett HM, Baker MA, Morrice JA, et al. 2005. Biogeochemical and metabolic responses to the flood pulse in a semiarid floodplain. Ecology 86: 220-34.

Vilizzi L, McCarthy BJ, and Scholz O. 2012. Managed and natural inundation: benefits for conservation of native fish in a semiarid wetland system. Aquatic Conserv 23: 37-50.

Vörösmarty CJ, McIntyre PB, Gessner MO, et al. 2010. Global threats to human water security and river biodiversity. Nature 467: 555-61.

Wang D. 2009. Population status, threats and conservation of the Yangtze finless porpoise. Chinese Sci Bull 54: 3473-84.

Ward J, Tockner K, and Schiemer F. 1999. Biodiversity of floodplain river ecosystems: ecotones and connectivity. Regul River 15: 125-39.

Zeug SC and Winemiller KO. 2008. Evidence supporting the importance of terrestrial carbon in a large-river food web. Ecology 89: 1733-43. 